How to Cite: Imamaliyeva, S.Z., Mekhdiyeva, I.F., Jafarov, Y.I., \& Babanly, M.B. (2021) Thermodynamic study of the thalliumthulium tellurides by EMF method. Bulletin of the University of Karaganda - Chemistry, 102(2), 43-52. https://doi.org/10.31489/2021Ch2/43-52

\author{
S.Z. Imamaliyeva*1, I.F. Mekhdiyeva ${ }^{1}$, Y.I. Jafarov ${ }^{2}$, M.B. Babanly ${ }^{1}$ \\ ${ }^{I}$ Institute of Catalysis and Inorganic Chemistry named after acad. M. Nagiyev, \\ Azerbaijan National Academy of Sciences, Baku, Azerbaijan; \\ ${ }^{2}$ Baku State University, Azerbaijan \\ ("Corresponding author's e-mail: samira9597a@gmail.com)
}

\title{
Thermodynamic study of the thallium-thulium tellurides by EMF method
}

\begin{abstract}
In this study the phase equilibria in the $\mathrm{Tl}_{2} \mathrm{Te}_{2}-\mathrm{Tl}_{2} \mathrm{Te}_{3}-\mathrm{TlTmTe}_{2}$ compositions area of the $\mathrm{Tl}-\mathrm{Tm}-\mathrm{Te}$ ternary system were studied by powder X-ray diffraction (PXRD) analysis. Based on PXRD data, the solid-phase equilibria diagram was plotted. The thermodynamic functions of the $\mathrm{Tl}_{9} \mathrm{TmTe}_{6}$ and $\mathrm{TlTmTe}_{2}$ ternary compounds were calculated by the electromotive forces method. The electrochemical cells of the following type (-) TmTe (s.) $\mid$ glycerol $+\mathrm{KCl}+\mathrm{TmCl}_{3} \mid(\mathrm{Tm}$ in alloys of Tl-Tm-Te system) (s.) (+) were assembled and their EMF were measured in the 300-450 K temperature range. Based on obtained EMF data for the $\mathrm{Tl}_{2} \mathrm{Te}_{3}-\mathrm{TlTe}_{-}$ $\mathrm{TlTmTe}_{2}$ and $\mathrm{TlTe}-\mathrm{TlTmTe}_{2}-\mathrm{Tl}_{9} \mathrm{TmTe}_{6}$ three-phase regions, the relative partial thermodynamic functions of TmTe in alloys were calculated. The combination of these functions with the partial molar functions of thulium in TmTe allowed calculating the corresponding partial functions of thulium in the above phase regions. The potential-forming reactions responsible for the indicated partial molar values were obtained based on constructed solid-phase equilibria diagram. Using indicated potential-forming reactions, for the first time, the standard thermodynamic functions of formation and standard entropies of the $\mathrm{Tl}_{9} \mathrm{TmTe}_{6}$ and $\mathrm{TlTmTe}_{2}$ compounds were calculated.
\end{abstract}

Keywords: $\mathrm{Tl}-\mathrm{Tm}-\mathrm{Te}$ system, $\mathrm{Tl}_{9} \mathrm{TmTe}_{6}, \mathrm{TlTmTe}_{2}$, powder X-ray diffraction analysis, solid-phase equilibria diagram, method of electromotive forces, concentration cells, thermodynamic functions.

\section{Introduction}

The presence of a wide range of functional properties (thermoelectric, optical, electronic) in chalcogenides of heavy elements makes them promising functional materials in numerous fields of modern technology, such as electronics, optoelectronics industry, photovoltaic and photo-detection applications, fiber-optical communication, etc. [1-6]. Moreover, the discovery of a topological insulators (TI) shown that these compounds also exhibit the properties of TI and can be used in spintronics and quantum computers, medicine, security systems $[7,8]$.

The introduction of heavy metal atoms as well as d- and f-elements into the crystal lattice of these compounds can lead to an improvement in their thermoelectric properties [9], and also give them additional functionality, for example, magnetic properties, as well as the properties of TI [10-13].

It is known that telluride $\mathrm{Tl}_{5} \mathrm{Te}_{3}$ exhibits thermoelectric properties [14]. Due to the peculiarities of the crystal lattice it has many ternary analogs of the types $\mathrm{Tl}_{9} \mathrm{AX}_{6}$ and $\mathrm{Tl}_{4} \mathrm{BX}_{3}$ (A-Sb, Bi, In, Au, rare-earth elements; B-Sn, $\mathrm{Pb}, \mathrm{Mo}, \mathrm{Cu}$, rare-earth elements; X-Se, Te) [15-22], also possessing several functional properties, namely optical [23, 24], thermoelectric [25-27], magnetic [28, 29], as well as topological insulators properties [30, 31]. In recent years in order to improve thermoelectric performance intensive work has been carried out to study solid solutions and doped phases based on these compounds [32-34].

Another class of thallium chalcogenides with the common formula $\mathrm{TlCX}_{2}(\mathrm{C}-\mathrm{Sb}, \mathrm{Bi}, \mathrm{In}, \mathrm{Ag}$, rare-earth elements) also possess many functional properties [10, 35-40].

For design and optimization of the synthesis and the growth of the single crystal conditions besides the phase diagram, accurate data of the thermodynamic functions are required [43-46]. Usually, the method of differential scanning calorimetry is used to determine the thermal effects of phase transformations and the heat capacity $[47,48]$. At the same time, the method of electromotive forces (EMF) has found wide application in practice due to the simplicity of measurements and their high accuracy. EMF measurements are often used to investigate the partial and integral thermodynamic functions of formation. In practice, the several modifications of the EMF method are used. In this case, liquid electrolytes [49-51], solid electrolytes [52, 53], as well as ionic liquids can serve as an electrolyte $[54,55]$. 
However, despite potential interest we did not find in the literature data on the thermodynamic properties of $\mathrm{Tl}_{9} \mathrm{LnTe}_{6}$ and $\mathrm{TlLnX}_{2}$ compounds. Considering the above, we have undertaken a comprehensive study of solid-phase equilibria and thermodynamic properties of the Tl-Gd-Te and Tl-Er-Te systems [41, 42].

In this experimental study, we present the results of the investigation of the solid-phase relations in the $\mathrm{Tl}_{2} \mathrm{Te}_{-} \mathrm{Tl}_{2} \mathrm{Te}_{3}-\mathrm{TlTmTe}_{2}$ system and the thermodynamic properties of the $\mathrm{Tl}_{9} \mathrm{TmTe}_{6}$ и $\mathrm{TlTmTe}_{2}$ ternary compounds by EMF method.

\section{Experimental}

Synthesis

The initial compounds and intermediate samples from the $\mathrm{Tl}_{2} \mathrm{Te}_{3}-\mathrm{TlTe}-\mathrm{TlTmTe}_{2}$ and $\mathrm{TlTe}-\mathrm{TlTmTe}_{2}-$ $\mathrm{Tl}_{9} \mathrm{TmTe}_{6}$ three-phase regions were synthesized from high-purity thallium (granules, $99.999 \%$ ), thulium (ingots, 99.9\%), tellurium (ingots $99.999 \%$ ), and telluride $\mathrm{Tl}_{2} \mathrm{Te}$ in evacuated quartz ampoules. After alloying at $1000 \mathrm{~K}$, non-homogenized intermediate samples were powdered, mixed, compressed into a tablet, and annealed further at $700 \mathrm{~K}$ for $1000 \mathrm{~h}$.

The congruently melting $\mathrm{Tl}_{2} \mathrm{Te}$ was synthesized by fusing thallium and tellurium in vacuumed $\left(\sim 10^{-2} \mathrm{~Pa}\right)$ quartz ampoule at $750 \mathrm{~K}$ followed by slow cooling.

The refractory compound TmTe was synthesized by ceramic method at $1000 \mathrm{~K}$ followed by annealing at $900 \mathrm{~K}$ for $1000 \mathrm{~h}$.

\section{Methodology}

Studies were carried out by powder X-ray phase diffraction analysis (Bruker D8 diffractometer with $\mathrm{CuK} \alpha_{1}$ radiation) and electromotive forces (EMF) method.

For the rational planning of thermodynamic experiments, we first studied the solid-phase equilibria of the $\mathrm{Tl}-\mathrm{Tm}-\mathrm{Te}$ system in the $\mathrm{Tl}_{2} \mathrm{Te}-\mathrm{Tl}_{2} \mathrm{Te}_{3}-\mathrm{TlTmTe}_{2}$ compositions area (Fig. 1).

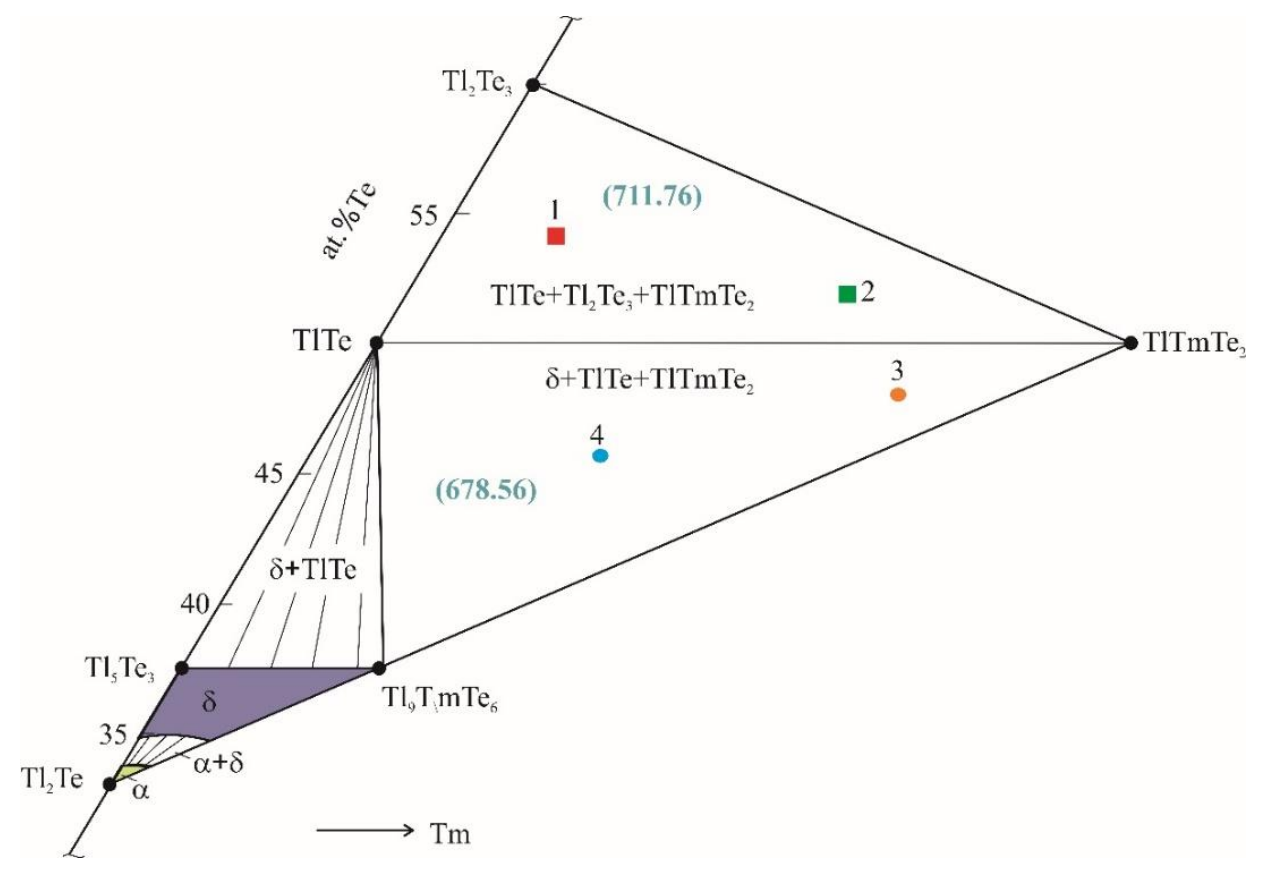

Figure 1. The solid-phase equilibria diagram of the $\mathrm{Tl}_{2} \mathrm{Te}-\mathrm{Tl}_{2} \mathrm{Te}_{3}-\mathrm{TlTmTe}_{2}$ subsystem. 1-4 - alloy compositions used for XRD and EMF measurements;

the numbers in brackets are the EMF values $(\mathrm{mV})$ of the cells type (1) in the three-phase regions

The data on phase relations in the $\mathrm{Tl}_{2} \mathrm{Te}-\mathrm{Tl}_{5} \mathrm{Te}_{3}-\mathrm{Tl}_{9} \mathrm{TmTe}_{6}$ composition area were taken from the previous study [56]. The formation of a wide area of solid solutions with the $\mathrm{Tl}_{5} \mathrm{Te}_{3}$ structure ( $\delta$-phase) was found for this system. Also it was established that $\delta$-phase is tie-lined to TITe (Fig. 1) [57]. As a result, a two-phase region $\delta+T l T e$ is formed on the phase diagram. Solid-phase equilibria diagram of the $\mathrm{Tl}_{2} \mathrm{Te}_{3}-\mathrm{Tl}_{2} \mathrm{Te}-\mathrm{TlTmTe}_{2}$ system also reflects the presence of three-phase regions $\mathrm{Tl}_{2} \mathrm{Te}_{3}-\mathrm{TlTe}-\mathrm{TITmTe}_{2}$ and $\mathrm{TITe}-\mathrm{TITmTe}_{2}-\mathrm{Tl}_{9} \mathrm{TmTe}_{6}$ (Fig.1). Their existence is confirmed based on powder diffraction patterns of selected alloys (Fig. 2, samples 1,4). 


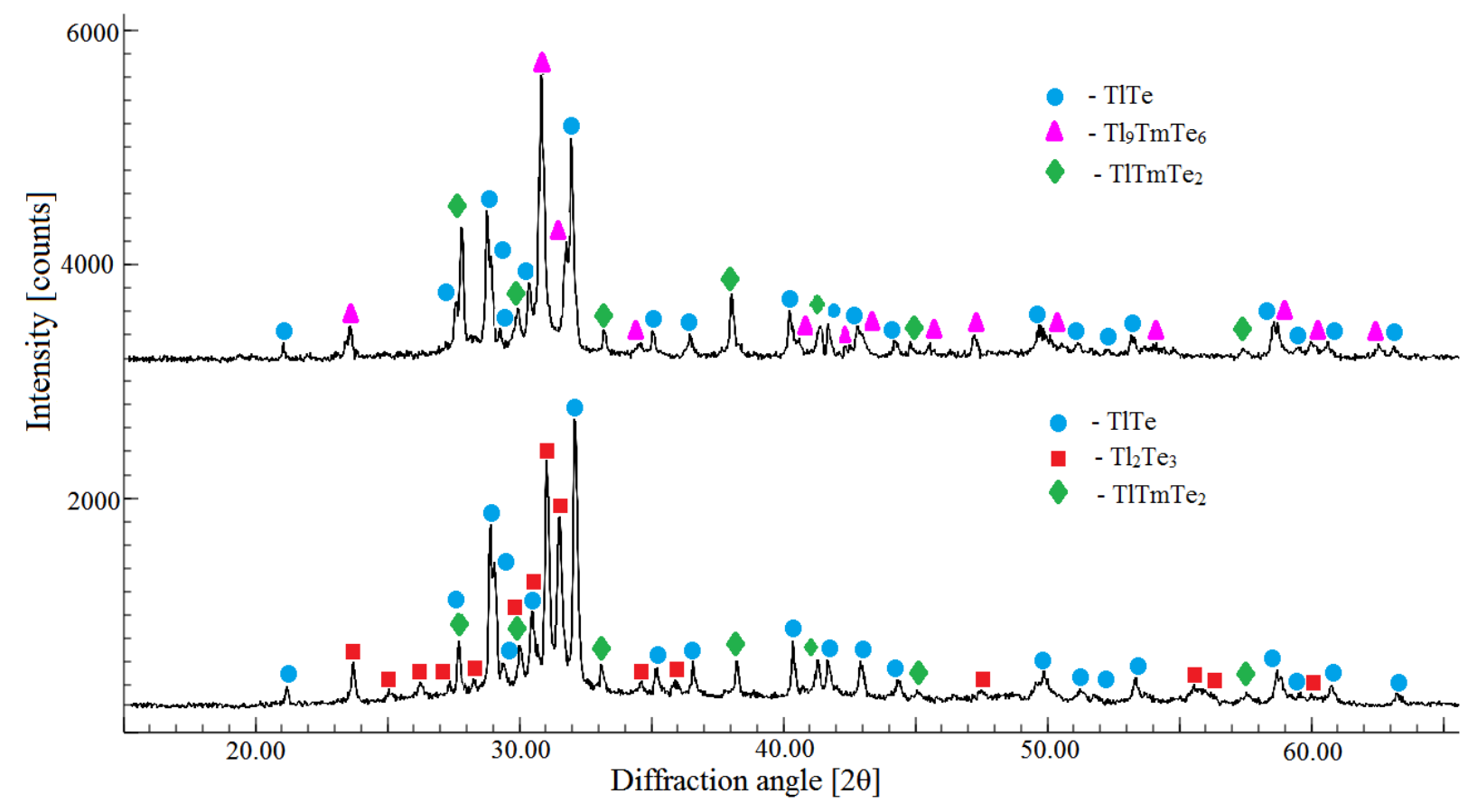

Figure 2. The powder X-ray diffractogramms of the alloys from $\mathrm{Tl}_{2} \mathrm{Te}_{3}-\mathrm{TlTe}-\mathrm{TlTmTe}_{2}$ and $\mathrm{TlTe}-\mathrm{TlTmTe}_{2}-\mathrm{Tl}_{9} \mathrm{TmTe}_{6}$ compositions areas

Thus, EMF measurements in the indicated three-phase regions can be used for calculations of the thermodynamic functions of the $\mathrm{Tl}_{9} \mathrm{TmTe}_{6}$ and $\mathrm{TlTmTe}_{2}$ ternary compounds.

The assembled electrochemical cell with a liquid electrolyte can be presented schematically as

$$
\text { (-) } \mathrm{TmTe} \text { (s.) } \mid \text { glycerol }+\mathrm{KCl}+\mathrm{TmCl}_{3} \mid \text { (Tm in alloys) (s.) (+). }
$$

In cells (1) a glycerol solution of $\mathrm{KCl}$ with addition of $\mathrm{TmCl}_{3}(0.1 \%)$ was used as the electrolyte. It is necessary to pay special attention to the salts $\left(\mathrm{KCl}\right.$ и $\left.\mathrm{TmCl}_{3}\right)$ and glycerol. They must be free from moisture and oxygen. Therefore glycerol was dehydrated and degassed before use by pumping at a temperature of $\sim 450 \mathrm{~K}$. Anhydrous $\mathrm{KCl}$ and $\mathrm{TmCl}_{3}$ were used. The electrolyte was stored in a sealed ampoule and used as required. Upon the introduction of the electrolyte in a cell, contact with air was minimal.

TmTe with a negligible ( 0.1 at.\%) tellurium excess was used as the left (negative) electrode. Our previous studies [41, 42] showed that using metallic lanthanide as the left electrode resulted in high EMF values. Right (positive) electrodes in the cells of type (1) were equilibrium alloys from $\mathrm{Tl}_{2} \mathrm{Te}_{3}-\mathrm{TlTe}-\mathrm{TlTmTe}_{2}$ and $\mathrm{TlTe}-$ $\mathrm{TlTmTe}_{2}-\mathrm{Tl}_{9} \mathrm{TmTe}_{6}$ three-phase regions. The synthesis of the alloys - right electrodes is described above. The methods for preparing electrodes and assembling an electrochemical cell are detailed described in [54, 55]. To control the reproducibility of the EMF results and their compliance with the phase diagram, 2 electrode-alloys with different compositions from each three-phase region were prepared.

The electrochemical cell described $[54,55]$ was assembled, evacuated, filled with argon, and placed in a cylindrical electric furnace. All contacts and current leads of the cell were kept at the same temperature. The first equilibrium EMF values were obtained after keeping the concentration cell at $\sim 350 \mathrm{~K}$ for $60 \mathrm{~h}$, followed by every 3-4 hours after the establishment of a certain temperature. The EMF data were considered equilibrium if they did not differ from each other upon repeated measurements at a given temperature by more than $0.2 \mathrm{mV}$, regardless of the direction of the temperature change. Within the experiment the EMF of each sample was measured 3 times at two constant temperatures. For example, for an alloy from the $\mathrm{Tl}_{2} \mathrm{Te}_{\mathrm{C}}-\mathrm{Tl}_{5} \mathrm{Te}_{3}-\mathrm{Tl}_{9} \mathrm{TmTe}_{6}$ phase region at $350.8 \mathrm{~K}$, EMF values were: $683.13,683.19,683.224$. Table 1 presents the averaged value of 683.18.

Keithley 21006 1/2 digital multimeter was used for EMF measurements. Most measurements were carried out when heating and cooling the cell in steps no more than $10^{\circ}$. The chromel-alumel thermocouples and a mercury thermometer (an accuracy of $\pm 0.5 \mathrm{~K}$ ) were used for measurements of the temperature of the electrochemical cell. 
The EMF measurements were conducted in 300-450 K temperature interval. The upper limit of the temperature interval of the EMF measurements was chosen so that the phase composition remained unchanged within the experiment. The mass measurement and X-ray diffraction analysis of electrodes before and after EMF measurements were used to control the reversibility of electrochemical cells and reproducibility of results. The mass and composition of the electrodes remained constant in the time of the experiment.

\section{Results and Discussion}

The obtained experimental data, i.e., pairs of temperature and EMF values are listed in Table 1.

Table 1

Experimentally determined data for temperature and EMF of the $\mathrm{Tl}_{2} \mathrm{Te}_{3}-\mathrm{TITe}_{3} \mathrm{TITmTe}_{2}$ and $\mathrm{TITe}_{\mathrm{T}} \mathrm{TITmTe}_{2}-\mathrm{Tl}_{9} \mathrm{TmTe}_{6}$ phase regions in the Tl-Tm-Te system

\begin{tabular}{|c|c|c|}
\hline \multirow{2}{*}{$\mathrm{T}, \mathrm{K}$} & \multicolumn{2}{|c|}{$\mathrm{E}, \mathrm{mV}$} \\
\hline & $\mathrm{TlTe}-\mathrm{TlTmTe}_{2}-\mathrm{Tl}_{9} \mathrm{TmTe}_{6}$ & $\mathrm{Tl}_{2} \mathrm{Te}_{3}-\mathrm{TlTe}-\mathrm{TlTmTe}_{2}$ \\
\hline 301.2 & 680.24 & 712.85 \\
\hline 306.7 & 679.15 & 711.34 \\
\hline 312.7 & 681.02 & 712.45 \\
\hline 318.3 & 679.84 & 714.64 \\
\hline 323.3 & 681.68 & 715.12 \\
\hline 328.2 & 681.82 & 713.13 \\
\hline 334.2 & 682.08 & 715.65 \\
\hline 340.1 & 680.62 & 713.94 \\
\hline 345.5 & 684.68 & 714.02 \\
\hline 350.8 & 683.18 & 718.12 \\
\hline 357.7 & 684.24 & 714.94 \\
\hline 362.2 & 683.21 & 719.08 \\
\hline 366.4 & 684.86 & 719.66 \\
\hline 371.5 & 684.86 & 716.06 \\
\hline 377.9 & 688.84 & 720.07 \\
\hline 382.9 & 687.68 & 717.98 \\
\hline 387.4 & 687.44 & 716.46 \\
\hline 392.3 & 685.02 & 719.66 \\
\hline 395.3 & 688.44 & 719.22 \\
\hline 402.1 & 688.68 & 722.12 \\
\hline 407.5 & 690.96 & 718.78 \\
\hline 412.3 & 688.12 & 719.83 \\
\hline 416.7 & 688.93 & 722.55 \\
\hline 421.3 & 687.87 & 721.88 \\
\hline 425.7 & 693.46 & 722.74 \\
\hline 431.1 & 692.21 & 722.66 \\
\hline 437.2 & 693.34 & 722.02 \\
\hline 442.7 & 692.66 & 724.33 \\
\hline 446.2 & 693.85 & 724.12 \\
\hline 449.2 & 693.99 & 725.97 \\
\hline
\end{tabular}

The EMF measurements data of the electrochemical cell of type (1) were in full agreement with the diagram of solid-phase equilibria of the $\mathrm{Tl}_{2} \mathrm{Te}-\mathrm{Tl}_{2} \mathrm{Te}_{3}-\mathrm{TlTmTe}_{2}$ system (Fig. 1). At a certain temperature the EMF value in the three-phase regions $\mathrm{Tl}_{2} \mathrm{Te}_{3}-\mathrm{TlTe}-\mathrm{TlTmTe}_{2}$ and $\mathrm{TlTe}-\mathrm{TlTmTe}_{2}-\mathrm{Tl}_{9} \mathrm{TmTe}_{6}$ were constant and changed during the transition from one phase to another.

The temperature dependences on EMF for all alloys of the Tl-Tm-Te system were linear (Fig.3). Also, the measurements results showed that, in addition to reproducibility, the numerical values of the EMF increase in the radial directions from $\mathrm{Tm}$ vertex of the $\mathrm{Tl}-\mathrm{Tm}-\mathrm{Te}$ concentration triangle, which is in agreement with the well-known thermodynamic principle [47, 48]. 


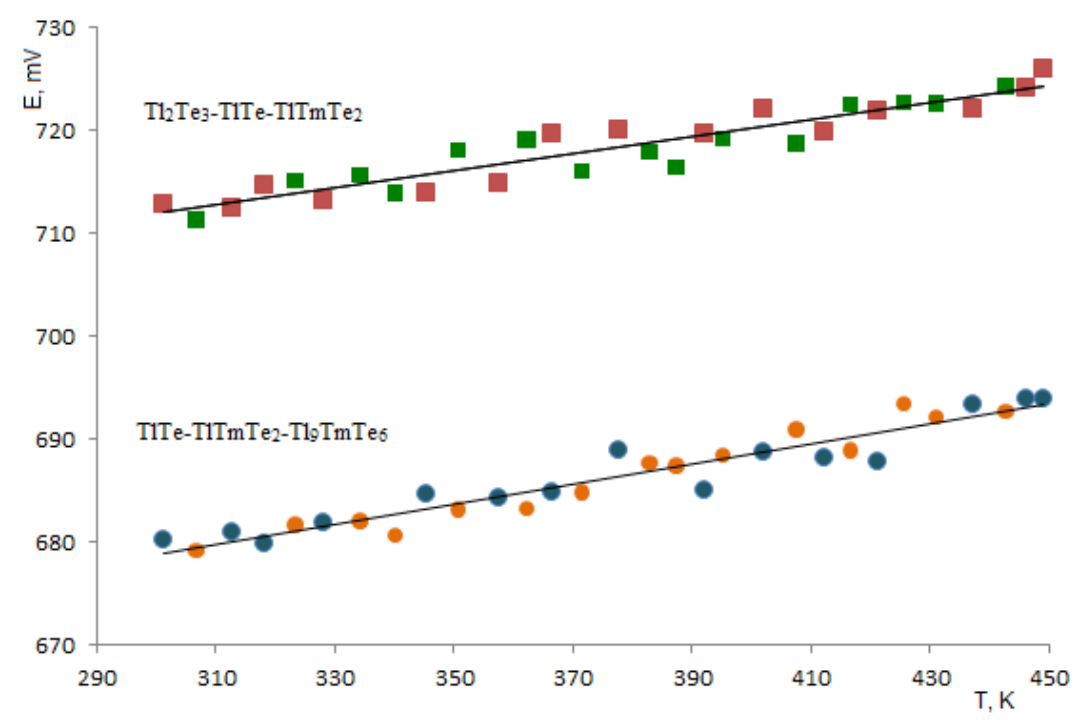

Figure 3. Temperature dependencies of EMF for alloys of the $\mathrm{Tl}_{2} \mathrm{Te}_{3}-\mathrm{TlTe}-\mathrm{TlTmTe}_{2}$ and $\mathrm{TlTe}-\mathrm{TlTmTe}_{2}-\mathrm{Tl}_{9} \mathrm{TmTe}_{6}$ phase areas of the Tl-Tm-Te system.

Alloys of different composition for each three-phase area are shown in different colors

Alloy designations are the same as in Figure 1.

Therefore, the data obtained were processed by the least-squares method, and temperature dependences of EMF were represented by the linear equation of type

$$
E=a+b T \pm t\left[\frac{\delta_{E}^{2}}{n}+\delta_{b}^{2}(T-\bar{T})^{2}\right]^{1 / 2}
$$

In equation (2) $a$ and $b$ are coefficients, $n$ is the number of pairs of values $E$ and $T$; $\bar{T}$ is average temperature in K, $t$ is Student's test, and $\delta_{E}^{2}$ and $\delta_{b}^{2}$ are the variances of individual EMF values and the constant $b$. With the number of experimental points $n=30$, and the confidence level equal to $95 \%$, the Student's test is $t \leq 2$. Table 2 lists the equations obtained.

The partial molar functions of thulium telluride in the alloys at $298 \mathrm{~K}$ (Table 3) were calculated using the following thermodynamic relations:

$$
\begin{gathered}
\Delta \overline{\boldsymbol{G}}_{T m T e}=-z F E ; \\
\Delta \overline{\boldsymbol{S}}_{T m T e}=z F\left(\frac{\partial E}{\partial T}\right)_{P}=z F b ; \\
\Delta \overline{\boldsymbol{H}}_{T m T e}=-z F\left[E-T\left(\frac{\partial E}{\partial T}\right)_{P}\right]=-z F a .
\end{gathered}
$$

In the equations (3)-(5), $\mathrm{z}$ is the charge of the potential-forming cation $\mathrm{Tm}^{3+}, \mathrm{F}$ is the Faraday constant,

\begin{tabular}{|c|c|c|}
\hline № & Phase area & $E, \mathrm{mV}=a+b T \pm 2\left[\delta_{E}^{2} / n+\delta_{b}^{2}(T-\bar{T})\right]^{1 / 2}$ \\
\hline 1 & $\mathrm{Tl}_{2} \mathrm{Te}_{3}+\mathrm{TlTe}+\mathrm{TlTmTe}_{2}$ & $687.07+0.0828 T \pm 2\left[\frac{2.1}{30}+3.5 \cdot 10^{-5}(T-378.2)\right]^{1}$ \\
\hline 2 & $\mathrm{TlTe}+\mathrm{Tl}_{9} \mathrm{TmTe}_{6}+\mathrm{TlTmTe}_{2}$ & $649.22+0.0984 T \pm 2\left[\frac{1.9}{30}+3.1 \cdot 10^{-5}(T-378.2)\right]^{1 /}$ \\
\hline
\end{tabular}
$a$ and $b$ are the constants in relation (2).

Ta a le 2

Temperature dependencies of the EMF for the cells of the type (1) in the 300-450 K temperature interval 
Ta b l e 3

Relative partial molar functions of thulium monotelluride in the alloys of the Tl-Tm-Te system at $\mathrm{T}=298 \mathrm{~K}$

\begin{tabular}{|c|c|c|c|}
\hline \multirow{2}{*}{ Phase area } & $-\overline{\Delta G}_{\mathrm{TmTe}}$ & $-\bar{\Delta}_{\mathrm{TmTe}}$ & \multirow{\Delta}{*}{$\begin{array}{c}\overline{\Delta S}_{\mathrm{TmTe}} \\
\mathrm{J} \cdot \mathrm{mol}^{-1} \cdot \mathrm{K}^{-1}\end{array}$} \\
\cline { 2 - 4 } & \multicolumn{2}{|c|}{$\mathrm{kJ} \cdot \mathrm{mol}^{-1}$} & $23.97 \pm 3.40$ \\
$\mathrm{Tl}_{2} \mathrm{Te}_{3}+\mathrm{TlTe}+\mathrm{TlTmTe}_{2}$ & $206.02 \pm 0.31$ & $198.88 \pm 1.30$ & $28.48 \pm 3.24$ \\
$\mathrm{TlTe} \mathrm{Tl}_{9} \mathrm{TmTe}_{6}+\mathrm{TlTmTe}_{2}$ & $196.42 \pm 0.30$ & $187.92 \pm 1.23$ & \\
\hline
\end{tabular}

These values represent the difference of the corresponding partial molar functions of thulium for the left and right electrodes of the cells of type (1). For example, for alloys from $\mathrm{Tl}_{2} \mathrm{Te}_{3}+\mathrm{TlTe}+\mathrm{TlTmTe}_{2}$ three-phase area

then

$$
\Delta \bar{G}_{\mathrm{TmTe}}(\text { in alloys })=\Delta \bar{G}_{\mathrm{Tm}} \text { (in alloy) }-\Delta \bar{G}_{\mathrm{Tm}}(\text { in TmTe) },
$$

$$
\Delta \bar{G}_{\mathrm{Tm}} \text { (in alloy) }=\Delta \bar{G}_{\mathrm{TmTe}} \text { (in alloy) }+\Delta \bar{G}_{\mathrm{Tm}}(\text { in TmTe) } .
$$

Therefore, the calculation of the partial thermodynamic functions of thulium in the above three-phase regions was carried out by summation of the data in Table 3 with the corresponding partial molar functions $T m$ in TmTe [58]: $\Delta \bar{G}_{T m}=-261.31 \pm 0.22 \mathrm{\kappa J} \cdot \mathrm{mol}^{-1}, \Delta \bar{H}_{T m}=-267.62 \pm 0.92 \mathrm{\kappa J} \cdot \mathrm{mol}^{-1}$, $\Delta \bar{S}_{T m}=-21.16 \pm 2.42 \mathrm{~J} \cdot \mathrm{mol}^{-1} \cdot \mathrm{K}^{-1}$. The obtained results are given in Table 4.

Table 4

\begin{tabular}{|c|c|c|c|}
\hline \multirow{2}{*}{ Phase area } & $-\overline{\Delta G}_{\mathrm{Tm}}$ & $-\overline{\Delta H}_{\mathrm{Tm}}$ & \multirow{2}{*}{$\begin{array}{c}\overline{\Delta S}_{\mathrm{Tm}} \\
\mathrm{J} \cdot \mathrm{mol}^{-1} \cdot \mathrm{K}^{-1}\end{array}$} \\
\hline & \multicolumn{2}{|c|}{$\mathrm{kJ} \cdot \mathrm{mol}^{-1}$} & \\
\hline $\mathrm{Tl}_{2} \mathrm{Te}_{3}+\mathrm{TlTe}+\mathrm{TlTmTe}_{2}$ & $467.33 \pm 0.53$ & $466.50 \pm 2.22$ & $2.78 \pm 5.82$ \\
\hline $\mathrm{TlTe}+\mathrm{Tl}_{9} \mathrm{TmTe}_{6}+\mathrm{TlTmTe}_{2}$ & $457.73 \pm 0.52$ & $455.54 \pm 2.15$ & $7.35 \pm 5.66$ \\
\hline
\end{tabular}

Relative partial molar functions of thulium in the alloys of the Tl-Tm-Te system at $\mathrm{T}=298 \mathrm{~K}$

The standard integral thermodynamic functions of the $\mathrm{TlTmTe}_{2}$ and $\mathrm{Tl}_{9} \mathrm{TmTe}_{6}$ compounds were calculated by the method of potential-forming reactions. According to the solid-phase equilibria diagram (Fig. 1), the values of the partial molar functions of thulium in the $\mathrm{Tl}_{2} \mathrm{Te}_{3}-\mathrm{TlTe}_{\mathrm{T}} \mathrm{TlTmTe}_{2}$ and $\mathrm{TlTe}-\mathrm{TlTmTe}_{2}-$ $\mathrm{Tl}_{9} \mathrm{TmTe}_{6}$ three-phase areas are thermodynamic functions of the potential formation reactions

$$
\mathrm{Tm}+\mathrm{Tl}_{2} \mathrm{Te}_{3}=\mathrm{TlTe}+\mathrm{TlTmTe}_{2}
$$

$\mathrm{Tm}+3 \mathrm{TlTe}=0.25 \mathrm{Tl}_{9} \mathrm{TmTe}_{6}+0.75 \mathrm{TlTmTe}_{2}$

According to relations (7) and (8), the standard thermodynamic functions of the formation of ternary compounds $\mathrm{TlTmTe}_{2}$ and $\mathrm{Tl}_{9} \mathrm{TmTe}_{6}$ can be calculated from the relations

$$
\begin{gathered}
\Delta_{f} Z^{0}\left(\mathrm{TlTmTe}_{2}\right)=\overline{\Delta Z}_{\mathrm{Tm}}+\Delta_{f} Z^{0}\left(\mathrm{Tl}_{2} \mathrm{Te}_{3}\right)-\Delta_{f} Z^{0}(\mathrm{TlTe}), \\
\Delta_{f} Z^{0}\left(\mathrm{Tl}_{9} \mathrm{TmTe}_{6}\right)=4 \overline{\Delta Z}_{\mathrm{Tm}}+12 \Delta_{f} Z^{0}(\mathrm{TlTe})-3 \Delta_{f} Z^{0}\left(\mathrm{TlTmTe}_{2}\right),
\end{gathered}
$$

$(\mathrm{Z} \equiv \mathrm{G}, \mathrm{H})$, while the standard entropy by using relations

$$
\begin{gathered}
S^{0}\left(\mathrm{TlTmTe}_{2}\right)=\overline{\Delta S}_{\mathrm{Tm}}+S^{0}(\mathrm{Tm})+S^{0}\left(\mathrm{Tl}_{2} \mathrm{Te}_{3}\right)-S^{0}(\mathrm{TlTe}), \\
S^{0}\left(\mathrm{Tl}_{9} \mathrm{TmTe}_{6}\right)=4 \overline{\Delta S}_{\mathrm{Tm}}+4 S^{0}(\mathrm{Tm})+12 S^{0}(\mathrm{TlTe})-3 S^{0}\left(\mathrm{TlTmTe}_{2}\right) .
\end{gathered}
$$

Using relations (9)-(12) in calculations, beside own experimental data (Table 4), the value of the standard entropy $\mathrm{Tm}\left(71.014 \pm 0.209 \mathrm{~kJ} \cdot \mathrm{mol}^{-1}\right)$ [59] as well as thermodynamic data for $\mathrm{TlTe}$ and $\mathrm{Tl}_{2} \mathrm{Te}_{3}$ (Table 5), determined by using the EMF method [60] and included in the database [59] were used.

When calculating relations (10) and (12), in addition to the partial molar functions of thulium in the threephase region $\mathrm{TlTe}+\mathrm{Tl}_{9} \mathrm{TmTe}_{6}+\mathrm{TlTmTe}_{2}$ we used the standard integral thermodynamic functions of the TIT$\mathrm{mTe}_{2}$ compound determined in this work (Table 5). 
Standard integral thermodynamic functions of thallium-thulium tellurides at $\mathrm{T}=\mathbf{2 9 8} \mathrm{K}$

\begin{tabular}{|c|c|c|c|}
\hline \multirow{2}{*}{ Compound } & $-\Delta_{f} G^{0}(298 \mathrm{~K})$ & $-\Delta_{f} H^{0}(298 \mathrm{~K})$ & \multirow{2}{*}{$S^{0}(298 \mathrm{~K})$} \\
\cline { 2 - 3 } & \multicolumn{2}{|c|}{$\mathrm{kJ} \cdot \mathrm{mol}^{-1} \cdot \mathrm{K}^{-1}$} \\
\hline TlTe [60] $^{-1}$ & $44.9 \pm 0.5$ & $115.9 \pm 1.5$ \\
$\mathrm{Tl}_{2} \mathrm{Te}_{3}[60]$ & $44.5 \pm 0.4$ & $90.0 \pm 1.0$ & $279.7 \pm 3.3$ \\
$\mathrm{TlTmTe}_{2}$ & $90.8 \pm 0.8$ & $511.6 \pm 3.7$ & $240.6 \pm 10.8$ \\
$\mathrm{Tl}_{9} \mathrm{TmTe}_{6}$ & $513.6 \pm 1.7$ & $826.2 \pm 25.7$ & $965.0 \pm 74.0$ \\
\hline
\end{tabular}

During the calculations of the partial thermodynamic functions of thulium (Table 4) and integral thermodynamic functions of ternary compounds (Table 5), the inaccuracies were determined by the uncertainty propagation method. The relatively high errors in the values of the enthalpy of formation and entropy can be explained by the fact that, in contrast to the usual potential-forming reactions with one final product, there are 2 final products in reactions (7) and (8). Therefore, when calculating the thermodynamic functions of $\mathrm{TlTmTe}_{2}$ and $\mathrm{Tl}_{9} \mathrm{TmTe}_{6}$ compounds according to relations (9)-(12), the thermodynamic functions of some compounds are subtracted from the general balance, while their errors are summed up.

\section{Conclusion}

In this paper we presented a set of experimental data on solid-phase relations in the Tl-Tm-Te ternary system in the $\mathrm{Tl}_{2} \mathrm{Te}-\mathrm{Tl}_{2} \mathrm{Te}_{3}-\mathrm{TlTmTe}_{2}$ composition interval and thermodynamic functions of the $\mathrm{TlTmTe}_{2}$ and $\mathrm{Tl}_{9} \mathrm{TmTe}_{6}$ compounds obtained by the powder XRD and EMF methods. The relative partial thermodynamic functions of TmTe and Tm in alloys were obtained based on the EMF measurements. The potential-forming reactions responsible for the above partial molar quantities were determined based on constructed solid-phase equilibria diagram, and the standard thermodynamic functions of formation and standard entropies of the TIT$\mathrm{mTe}_{2}$ and $\mathrm{Tl}_{9} \mathrm{TmTe}_{6}$ compounds were calculated for the first time.

\section{Acknowledgment}

The work has been carried out within the framework of the International Joint Research Laboratory "Advanced Materials for Spintronics and Quantum Computing" (AMSQC) established between the Institute of Catalysis and Inorganic Chemistry of ANAS (Azerbaijan) and Donostia International Physics Center (Basque Country, Spain) and partially supported by the Science Development Foundation under the President of the Republic of Azerbaijan, a grant EİF/MQM/Elm-Tehsil-1-2016-1(26)-71/01/4-M-33.

On behalf of all authors, the corresponding author states that there is no conflict of interest.

\section{References}

1 Liu, X., Lee, S., Furdyna, J.K., Luo, T., \& Zhang, Y.H. (2019). Chalcogenide. From 3D to $2 D$ and Beyond. Elsevier.

2 Alonso-Vante, N. (2018). Chalcogenide Materials for Energy Conversion: Pathways to Oxygen and Hydrogen Reactions. Publisher Springer International Publishing AG

3 Scheer, R., \& Hans-Werner, S. (2011). Chalcogenide Photovoltaics: Physics, Technologies, and Thin Film Devices. Wiley$\mathrm{VCH}$.

4 Woodrow, Ph. (2018). Chalcogenides: Advances in Research and Applications. Nova.

5 Ahluwalia, G.K. (2016). Applications of Chalcogenides: S, Se, and Te. Springer.

6 Berger, L.I. (1997). Semiconductor Materials. CRC Press, Boca Raton, FL.

7 Holtgrewe, K., Mahatha, S.K., Sheverdyaeva, P.M., Moras P., Flammini, R., \& Colonna, S., et al. (2020). Topologization of $\beta$-antimonene on $\mathrm{Bi}_{2} \mathrm{Se}_{3}$ via proximity effects. Scientific Reports, 10, 14619-14612. https://doi.org/10.1038/s41598-020-71624-4

8 Flammini, R., Colonna, S., Hogan, C., Mahatha, S., Papagno, M., \& Barla, A., et al. (2018). Evidence of $\beta$-antimonene at the $\mathrm{Sb} / \mathrm{Bi}_{2} \mathrm{Se}_{3}$ interface. Nanotechnology, 29(6), 065704-8. https://doi.org/ 10.1088/1361-6528/aaa2c4

9 Ioffe, A.F. (1957). Semiconductor Thermoelements and Thermoelectric Cooling. Infosearch Limited, London.

10 Filnov, S.O., Klimovskikh, I.I, Estyunin, D.A., Fedorov, A., Voroshnin, V., \& Koroleva, A.V., et al. (2020). Probe-dependent Dirac-point gap in the gadolinium-doped thallium-based topological insulator $\mathrm{TlBi}_{0.9} \mathrm{Gd}_{0.1} \mathrm{Se}_{2}$. Physical Review B, 102 , $085149-7$. https://doi.org/10.1103/PhysRevB.102.085149

11 Usanmaz, D., Pinku, N., Toher, C., Plata, J.J., Friedrich, R., \& Fornari, M., et al. (2018). Spinodal Superlattices of Topological Insulators. Chemical Materials, 30(7), 2331-2340. https://doi.org/10.1021/acs.chemmater.7b05299

12 Shi, Y., Mashmoushi, N., Wegner, W., Jafarzadeh, P., Sepahi, Z., Assoud, A., \& Kleinke, H. (2019). Ultralow thermal conductivity of $\mathrm{Tl}_{4} \mathrm{Ag}_{18} \mathrm{Te}_{11}$. Journal of Material Chemistry C, 7, 8029-8036. DOI: 10.1039/c9tc02029b 
13 Ong, M., Hammouri, M., \& Jishi, R.A. (2018). Ab Initio Study of Optoelectronic and Magnetic Properties of Ternary Chromium Chalcogenides. Advances in Materials Science and Engineering, 1-6. DOI: 10.1155/2018/3762451

14 Matsumoto, H., Kurosaki, K., Muta, H., \& Yamanaka, Sh. (2009). Thermoelectric Properties of the Thallium-Tellurium Binary Compounds. Materials Transactions, 50(7), 1582-1585. https://doi.org/10.2320/matertrans.E-M2009803

15 Wacker, K. (1991). Die kristalstrukturen von $\mathrm{Tl}_{9} \mathrm{SbSe}_{6}$ und $\mathrm{Tl}_{9} \mathrm{SbTe}_{6}$. Z. Kristallogr. Supple, 3, 281.

16 Doert, T., \& Böttcher, P. (1994). Crystal structure of bismuthnonathalliumhexatelluride BiT19Te6. Z. Kristallogr., $209,95$. https://doi.org/10.1524/zkri.1994.209.1.95.15

17 Bradtmöller, S., \& Böttcher, P. (1993). Darstellung und kristallostructur von $\mathrm{SnTl}_{4} \mathrm{Te}_{3}$ und $\mathrm{PbTl}_{4} \mathrm{Te}_{3}$. Zeitschrift für anorganische und allgemeine Chemie, 619, 1155-1160. https://doi.org/10.1002/zaac.19936190702

18 Imamaliyeva, S.Z., Babanly, D.M., Tagiev, D.B., \& Babanly, M.B. (2018). Physicochemical Aspects of Development of Multicomponent Chalcogenide Phases Having the $\mathrm{Tl}_{5} \mathrm{Te}_{3}$ Structure. A Review Russian Journal of Inorganic Chemistry, 63, $1703-1724$. https://doi.org/10.1134/S0036023618130041

19 Imamaliyeva, S.Z. (2020). $\mathrm{Tl}_{4} \mathrm{GdTe}_{3}$ and $\mathrm{Tl}_{4} \mathrm{DyTe}_{3}$ - Novel Structural $\mathrm{Tl}_{5} \mathrm{Te}_{3}$ Analogues. Physics and chemistry of solid State, 21(3), 492-495. DOI: $10.15330 /$ pcss.21.3.492-495

20 Imamaliyeva, S.Z. (2020). New thallium tellurides with rare earth elements. Condensed Matter and Interphases. 4, 460-465. https://doi.org/10.15330/pcss.21.3.492-495

21 Bradtmöller, S., \& Böttcher, P. (1994). Crystal structure of copper tetra thallium tritelluride $\mathrm{CuTl}_{4} \mathrm{Te}_{3}$. Zeitschrift für Kristallographie, 209(1), 97. https://doi.org/10.1524/zkri.1994.209.1.97

22 Bradtmöller, S., \& Böttcher, P. (1994). Crystal structure of molybdenum tetra thallium tritelluride, MoTl $\mathrm{Te}_{3}$. Zeitschrift für Kristallographie, 209(1), 75. https://doi.org/10.1524/zkri.1994.209.1.75

23 Piasecki, M., Brik, M.G., \& Barchiy, I.E. (2017). Band structure, electronic and optical features of $\mathrm{Tl}_{4} \mathrm{SnX} \mathrm{X}_{3}(\mathrm{X}=\mathrm{S}, \mathrm{Te})$ ternary compounds for optoelectronic applications. Journal of Alloys and Compounds, 710, 600-607. https://doi.org/10.1016/j.jallcom.2017.03.280

24 Barchij, I.E., Sabov, M., \& El-Naggar, A.M. (2016). $\mathrm{Tl}_{4} \mathrm{SnS}_{3}, \mathrm{Tl}_{4} \mathrm{SnSe}_{3}$ and $\mathrm{Tl}_{4} \mathrm{SnTe}_{3}$ crystals as novel IR induced optoelectronic materials. Journal of Materials Science: Mater Electron, 27, 3901-3905. https://doi.org/10.1007/s10854-015-4240-4

25 Kurosaki, K., Uneda, H., Muta, H., \& Yamanaka, S. (2004). Thermoelectric properties of thallium antimony telluride. Journal of Alloys and Compounds, 376, 43-48, https://doi.org/10.1016/j.jallcom.2004.01.018

26 Guo, Q., \& Kleinke, H. (2015). Thermoelectric properties of hot-pressed (Ln = La, Ce, Pr, Nd, Sm, Gd, Tb) and Tl $1_{10-x} \mathrm{Lax}_{x} \mathrm{Te}_{6}$ $(0,90<\mathrm{x}<1,05)$. Journal of Alloys and Compounds, 630,37-42. https://doi.org/10.1016/j.jallcom.2015.01.025

27 Heinke, F., Eisenburger, L., \& Schlegel, R. (2017). The Influence of Nanoscale Heterostructures on the Thermoelectric Properties of Bi-substituted $\mathrm{Tl}_{5} \mathrm{Te}_{3}$. Zeitschrift für anorganische und allgemeine Chemie, 643, 447-454. https://doi.org/10.1002/zaac.201600449

28 Bangarigadu-Sanasy, S., Sankar, C.R., Dube, P.A., Greedan, J.E., \& Kleinke, H. (2014). Magnetic properties of $\mathrm{Tl}_{9} \mathrm{LnTe}_{6}$, $\mathrm{Ln}=\mathrm{Ce}, \mathrm{Pr}, \mathrm{Tb}$ and Sm. Journal of Alloys and Compounds, 589, 389-392. https://doi.org/10.1016/j.jallcom.2013.11.229

29 Isaeva, A., Schönemann, R., \& Doert, T. (2020). Syntheses, crystal structure and magnetic properties of $\mathrm{Tl}_{9} \mathrm{RETe}_{6}(\mathrm{RE}=\mathrm{Ce}$, Sm, Gd). Crystals - Open Access Journal, 10(4), 1-11. https://doi.org/10.3390/cryst10040277

30 Arpino, K.E., Wasser, B.D., \& McQueen, T.M. (2015). Superconducting Dome and Crossover to an Insulating State in $\left[\mathrm{Tl}_{4}\right] \mathrm{Tl}_{1-\mathrm{x}} \mathrm{Sn}_{\mathrm{x}} \mathrm{Te}_{3}$. APL Materials, 3(4), 041507-8. https://doi.org/10.1063/1.4913392

31 Niu, C., Dai, Y., Huang, B., Bihlmayer, G., Mokrousov, Y., Wortmann, D., \& Blügel, S. (2014). Natural three-dimensional topological insulators in $\mathrm{Tl}_{4} \mathrm{PbTe}_{3}$ and $\mathrm{Tl}_{4} \mathrm{SnTe}_{3}$. Frühjahrstagung der Deutschen Physikalischen Gesellschaft, 01899.

32 Waqas, M.Kh., Altaf, U.R., Tufail, M., Ibrar, M., Wiqar, H. Sh., Waqar, A. S., \& Gul, B. (2020). Toward controlled thermoelectric properties of $\mathrm{Pb}$ and $\mathrm{Sb}$ co-doped nanostructured Thallium Telluride for energy applications. Materials Research Express 7 , 105010-13. https://doi.org/10.1088/2053-1591/abbb54

33 Guo, Q., Assoud, A., \& Kleinke, H. (2014). Improved Bulk Materials with Thermoelectric Figure-of-Merit Greater than 1: $\mathrm{Tl}_{10-\mathrm{x}} \mathrm{Sn}_{\mathrm{x}} \mathrm{Te}_{6}$ and $\mathrm{Tl}_{10-\mathrm{x}} \mathrm{Pb}_{\mathrm{x}} \mathrm{Te} \mathrm{e}_{6}$ Materials Science. Advanced Energy Materials, 4(14), 1400348-8. https://doi.org/10.1002/aenm.201400348

34 Kuropatwa, B.A., Guo, Q., Assoud, A., \& Kleinke, H. (2014). Optimization of the Telluride $\mathrm{Tl}_{10-\mathrm{x}-\mathrm{y}} \mathrm{Sn}_{\mathrm{x}} \mathrm{Bi}_{\mathrm{y}} \mathrm{Te}_{6}$ for $\mathrm{Thermoe}$ lectric Properties. Zeitschrift für anorganische und allgemeine Chemie, 640, 774-780. https://doi.org/10.1002/zaac.201200284

35 Singh, B., Sharma, A., Lin, H., Hasan, M. Z., Prasad, R., \& Bansil, A. (2012). Topological electronic structure and Weyl semimetal in the TlBiSe 2 class of semiconductors. Physical Review B, 86, 115208-7. DOI: 10.1103/PhysRevB.86.115208

36 Pielmeier, F., Landolt, G., Slomski, B., Mu, S., Berwanger, J., \& Eich, A., et al. (2015). Response of the topological surface state to surface disorder in TIBiSe2. New Journal of Physics, 17, 023067-8. https://doi.org/10.1088/1367-2630/17/2/023067

37 Ding, G., He, J., Cheng, Z., Wang, X., \& Li, S. (2018). Low lattice thermal conductivity and promising thermoelectric figure of merit of Zintl type TIInTe2. Journal of Materials Chemistry, 6, 13269-13274. https://doi.org/10.1039/C8TC03492C

38 Shi, Y., Guo, Q., Cheng, X., Jafarzadeh, P., Macario, L. R., Menezes, L., \& Kleinke, H. (2019). Thermoelectric properties of $\mathrm{TlSBTe}_{2}$ doped with In and Yb. Journal of Alloys and Compounds, 795, 1-7. https://doi.org/10.1016/j.jallcom.2019.04.294

39 Sankar, C.R., Bangarigadu-Sanasy, S., \& Kleinke, H. (2012). Thermoelectric properties of $\mathrm{TlGdQ}_{2}(\mathrm{Q}=\mathrm{Se}, \mathrm{Te})$ and $\mathrm{Tl} 9 \mathrm{GdTe} 6$. Journal of Electronic Materials, 41, 1662-1666. https://doi.org/10.1007/s11664-011-1846-Z

40 Duczmal, M. (2003). Structure, wlasciwosci magnetzcyne i pole krzstalicyne w potrojnzch chalkogenkach lantonowcow i talu $\mathrm{TlLnX}_{2}(X=S$, Se lub Te). Monografie, Politechniki Wroclawskiej.

41 Imamalieva, S.Z., Babanly, D.M., Gasanly, T.M., Tagiev, D.B., \& Babanly, M.B. (2018). Thermodynamic Properties of $\mathrm{Tl}_{9} \mathrm{GdTe}_{6}$ and $\mathrm{TlGdTe}_{2}$. Russian Journal of Physical Chemistry A, 92 (11), 2111-2117. https://doi.org/10.1134/S0036024418110158

42 Imamaliyeva, S.Z., Mekhdiyeva, I. F., Babanly, D.M., Zlomanov, V.P., Tagiyev, D.B., \& Babanly, M.B. (2020). Solid-Phase Equilibria in the $\mathrm{Tl}_{2} \mathrm{Te}_{2} \mathrm{Tl}_{2} \mathrm{Te}_{3}-\mathrm{TlErTe}_{2}$ System and the Thermodynamic Properties of the $\mathrm{Tl}_{1} \mathrm{ErTe}_{6}$ and $\mathrm{TlErTe}_{2}$ Compounds, Russian Journal of Inorganic Chemistry. 65(11), 1762-1769. https://doi.org/10.1134/S0036023620110066 
43 Babanly, M.B., Mashadiyeva, L.F., Babanly, D.M., Imamaliyeva, S.Z., Taghiyev, D.B., \& Yusibov, Y.A. (2019). Some aspects of complex investigation of the phase equilibria and thermodynamic properties of the ternary chalcogenid systems by the EMF method. Russian Journal of Inorganic Chemistry, 64 (13), 1649-1671. https://doi.org/10.1134/S0036023619130035

44 Imamaliyeva, S.Z. (2018). Phase diagrams in the development of thallium-REE tellurides with $\mathrm{Tl}_{5} \mathrm{Te}_{3}$ structure and multicomponent phases based on them. Condensed Matter and Interphases, 20(3), 332-347. https://doi.org/10.17308/kcmf.2018.20/570

45 Matsushita, T., \& Mukai, K. (2018). Chemical Thermodynamics in Materials Science: From Basics to Practical Applications, Springer, 257

46 Morachevsky, A.G., Voronin, G.F., Geyderich, V.A., \& Kutsenok, I.B. (2003). Electrochemical methods of investigation in thermodynamics of metal systems. Akademkniga Publishing, 334.

47 Jain, A., \& Kandan, R. (2018). Determination of the thermodynamic stability of europium boride (EuB6). Thermal Analysis and Calorimetry, 132(1), 275-283. https://doi.org/10.1007/s10973-017-6876-1

48 Dahshan, A., Alharbi, S.R., Aly, K.A., \& Saddeek, Y. (2020). Thermal, mechanical, electrical and thermoelectric properties of Bi-As-Se glasses. Thermal Analysis and Calorimetry, 140(1), 125-131. https://doi.org/10.1007/s10973-019-08810-8

49 Vassiliev, V.P., Lysenko, V., \& Bros, J. (2019). Thermodynamic study of the Ag-In-Sn system by the EMF method. Journal of Alloys and Compounds, 790, 370-376. https://doi.org/10.1016/J.JALLCOM.2019.03.016

50 Imamaliyeva, S.Z., Mehdiyeva, I.F., Taghiyev, D.B., \& Babanly, M.B. (2020). Thermodynamic investigations of the erbium tellurides by EMF method. Physics and Chemistry of Solid State, 21(2), 312-318. https://doi.org/10.15330/pcss.21.2.312-318

51 Imamaliyeva, S.Z., Babanly, D.M., Zlomanov, V.P., Taghiyev, D.B., \& Babanly, M.B. (2020). Thermodynamic properties of terbium tellurides. Condensed Matter and Interphases, 4, 453-459. https://doi.org/10.17308/kcmf.2020.22/3116

52 Moroz, M., Tesfaye, F., Demchenko, P., Prokhorenko, M., \& Lindberg, D. (2018). Phase equilibria and thermodynamics of selected compounds in the Ag-Fe-Sn-S system. Journal of Electronic Materials, 47 (9), 5433-5442. https://doi.org/10.1007/s11664018-6430-3

53 Moroz M., Tesfaye F., Demchenko P., Prokhorenko M., Kogut Y., \& Pereviznyk O., et al. (2020). Solid-state electrochemical synthesis and thermodynamic properties of selected compounds in the Ag-Fe- $\mathrm{Pb}-\mathrm{Se}$ system. Solid State Science, 107, $106344-9$. https://doi.org/10.1016/j.solidstatesciences.2020.106344

54 Aliev, Z.S. Musayeva, S.S., Imamaliyeva, S.Z., \& Babanly, M.B. (2018). Thermodynamic study of antimony chalcoiodides by EMF method with an ionic liquid. Journal of Thermal Analysis and Calorimetry, 133(2), 1115-1120. https://doi.org/10.1007/s10973$017-6812-4$

55 Imamaliyeva, S.Z., Musayeva, S.S., Babanly, D.M., Jafarov, Y.I., Tagiyev, D.B., \& Babanly, M.B. (2019). Determination of the thermodynamic functions of bismuth chalcoiodides by EMF method with morpholinium formate as electrolyte. Thermochimica Acta, 679, 178319-7. https://doi.org/10.1016/j.tca.2019.178319

56 Imamaliyeva, S.Z., Mekhdiyeva, I.F., Amiraslanov, I.R., \& Babanlı, M.B. (2017). Phase equilibria in the $\mathrm{Tl}_{2} \mathrm{Te}_{\mathrm{T}}-\mathrm{Tl}_{5} \mathrm{Te}_{3}-$ $\mathrm{Tl}_{9} \mathrm{TmTe}_{6}$ section of the Tl-Tm-Te system. Phase equilibria and diffusion, 38(5), 764-770. https://doi.org/10.1007/s11669-017-05645

57 Mekhdiyeva, I.F. (2021). Phase equilibria in the T1Te-Tl9TmTe6 system. Azerbaijan Chemical Journal, 1, 32-37.

58 Imamaliyeva, S.Z., Mekhdiyeva, I.F., Gasymov, V.A., Babanli, D.M., Taghiyev, D.B., \& Babanli, M.B. (2021). Solid-phase equilibria and thermodynamic properties of phases of the Tm-Te system. Russian Journal of Physical Chemistry. C, 95(5), 926-932.

59 Thermal constants of substances: Database. Version 2, 2006. http://www.chem.msu.ru/cgi-bin/tkv.pl?show=welcome.html/welcome.html

60 Vasilev, V.P., Nikolskaya, A.V., Gerasimov, Ya.I., Kuznetsov, A.F. (1969). Thermodynamic investigation of thallium telluride by the electromotive force method. Neorg. Mater. 4(7), 1040-1047.

\title{
С.З. Имамалиева, И.Ф. Мехдиева, Я.И. Джафаров, М.Б. Бабанлы
}

\section{Талий-тулий теллуридтерін ЭКК әдісімен термодинамикалық зерттеу}

\begin{abstract}
Мақалада $\mathrm{Tl}_{2} \mathrm{Te}-\mathrm{Tl}_{2} \mathrm{Te}_{3}-\mathrm{TlTmTe} 2$ композициялар диапазонындағы фазалық тепе-теңдікті Tl-Tm-Te үштік жүйесінің ұнтақты рентгендік дифракциясы арқылы зерттеу нәтижелері келтірілген. XRD деректері негізінде қатты фазалық тепе-теңдік диаграммасы құрылды. Tl9 $\mathrm{TmTe}_{6}$ және TlTmTе2 үштік қосылыстарының термодинамикалық қасиеттері электр қозғаушы күштер әдісімен анықталды. (-) TmTe (қатты) типіндегі электрохимиялық ұяшықтар жиналды (қатты.) | глицерин $+\mathrm{KCl}+\mathrm{TmCl}_{3} \mid$ (Tl Tl-Tm-Te жүйесінің қорытпаларында) (қатты) (+) және олардың ЭҚК температурасы 300-450 К температурасында өлшенді. Алынған ЭҚК деректері негізінде үш фазалы аймақтар үшін $\mathrm{Tl}_{2} \mathrm{Te}_{3}-\mathrm{TlTe}_{-}$ $\mathrm{TlTmTe}_{2}$ және $\mathrm{TlTe}_{\mathrm{T}} \mathrm{TlTmTe}_{2}-\mathrm{Tl}_{9} \mathrm{TmTe}_{6}$, қорытпалардағы TmTe салыстырмалы ішінара термодинамикалық функциялары анықталды. Бұл функцияларды тулийдің TmТе ішінара молярлық функцияларымен біріктіре отырып, жоғарыда аталған фазалық аймақтардағы тулийдің сәйкес ішінара функциялары есептеледі. Қатты фазалық тепе-теңдік сызбасын қолдана отырып, көрсетілген ішінара молярлық шамаларға жауап беретін потенциал түзуші реакцияларды пайдаланып, Tl9TmTе6 және $\mathrm{TlTmTe}_{2}$ қосылыстарының стандартты термодинамикалық функциялары және стандартты энтропиялары есептелді.
\end{abstract}

Кілm сөздер: Tl-Tm-Те жүйесі, Tl9TmTе6, TlTmTe2, функционалды материалдар, рентгендікфазалық талдау, қаттыфазалық тепе-теңдік диаграммасы, электр қозғаушы күштер әдісі, термодинамикалық функциялар. 


\author{
С.3. Имамалиева, И.Ф. Мехдиева, Я.И. Джафаров, М.Б. Бабанлы
}

\title{
Термодинамическое исследование теллуридов талия-тулия методом ЭДС
}

\begin{abstract}
В статье представлены результаты исследования фазовых равновесий в области составов $\mathrm{Tl}_{2} \mathrm{Te}_{\mathrm{T}}-\mathrm{Tl}_{2} \mathrm{Te}_{3}-$ $\mathrm{TlTmTe}_{2}$ тройной системы Tl-Tm-Tе методом порошковой рентгеновской дифракции. На основании данных РФА построена диаграмма твердофазных равновесий. Термодинамические свойства тройных соединений $\mathrm{Tl}_{9} \mathrm{TmTe} 6$ и TITmTe2 определены методом электродвижущих сил. Были собраны электрохимические ячейки типа (-) TmTe (тв.) | глицерин $+\mathrm{KCl}+\mathrm{TmCl}_{3} \mid(\mathrm{Tm}$ в сплавах системы Tl-Tm-Te) (тв.) (+) и измерены их ЭДС в интервале температур 300-450 К. На основании полученных данных ЭДС для трехфазных областей $\mathrm{Tl}_{2} \mathrm{Te}_{3}-\mathrm{TlTe}-\mathrm{TlTmTe}_{2}$ и $\mathrm{TlTe}_{\mathrm{T}} \mathrm{TlTmTe}_{2}-\mathrm{Tl}_{9} \mathrm{TmTe}_{6}$ определены относительные парциальные термодинамические функции TmTe в сплавах. Комбинируя эти функции с парциальными молярными функциями тулия в TmTe, вычислены соответствующие парциальные функции тулия в указанных выше фазовых областях. Используя диаграмму твердофазных равновесий, составлены потенциалобразующие реакции, отвечающие за указанные парциальные молярные величины. С использованием составленных потенциалобразующих реакций впервые рассчитаны стандартные термодинамические функции образования и стандартные энтропии соединений Tl9TmTe6 и $\mathrm{TlTmTe}_{2}$.
\end{abstract}

Ключевые слова: система Tl-Tm-Te, Tl9TmTe6, TlTmTe2, функциональные материалы, рентгенофазовый анализ, диаграмма твердофазных равновесий, метод электродвижущих сил, термодинамические функции.

\section{Information about authors:}

Imamaliyeva, Samira Zakir - PhD on chemistry, Associate professor, Senior researcher, Institute of Catalysis and Inorganic Chemistry named after acad. M. Nagiyev, Azerbaijan National Academy of Sciences, 113, H. Javid ave., Baku, AZ-1143, Azerbaijan; e-mail: samira9597a@gmail.com; https://orcid.org/00000001-8193-2122

Mekhdiyeva, İlaha Firudin - PhD student, researcher, Institute of Catalysis and Inorganic Chemistry named after acad. M. Nagiyev, Azerbaijan National Academy of Sciences, 113, H. Javid ave., Baku, AZ-1143, Azerbaijan; e-mail: mehdiyeva.ilahe2@gmail.com; https://orcid.org/0000-0002-1106-0207

Jafarov, Yasin Isa - Doctor on chemistry, Associate professor, Baku State University, 23, Z, Khalilov str., Baku, Az-1048, Azerbaijan; e-mail: yasin.cafarov@ hotmail.com; https://orcid.org/0000-0002-6597-2252

Babanly, Mahammad Baba - corresponding member of ANAS, doctor on chemistry, deputy-director, Institute of Catalysis and Inorganic Chemistry named after acad. M. Nagiyev, Azerbaijan National Academy of Sciences, 113, H. Javid ave., Baku, AZ-1143, Azerbaijan; e-mail: babanlymb@gmail.com; https://orcid.org/0000-0001-5962-3710 